This item was submitted to Loughborough's Research Repository by the author.

Items in Figshare are protected by copyright, with all rights reserved, unless otherwise indicated.

\title{
Emerging applications of low temperature gas plasmas in the food industry
}

PLEASE CITE THE PUBLISHED VERSION

http://dx.doi.org/10.1116/1.4914029

\section{PUBLISHER}

(C) American Vacuum Society

\section{VERSION}

AM (Accepted Manuscript)

\section{PUBLISHER STATEMENT}

This work is made available according to the conditions of the Creative Commons Attribution-NonCommercialNoDerivatives 4.0 International (CC BY-NC-ND 4.0) licence. Full details of this licence are available at: https://creativecommons.org/licenses/by-nc-nd/4.0/

\section{LICENCE}

CC BY-NC-ND 4.0

\section{REPOSITORY RECORD}

Shaw, Alexander H., Gilbert Shama, and Felipe Iza. 2019. "Emerging Applications of Low Temperature Gas Plasmas in the Food Industry". figshare. https://hdl.handle.net/2134/17567. 


\title{
Emerging Applications of Low Temperature Gas Plasmas in the Food Industry
}

\author{
Running title: Emerging Applications of Plasmas in the Food Industry \\ Running Authors: Shaw et al.
}

\begin{abstract}
Alex Shaw and Felipe Iza
Loughborough University, School of Electronic, Electrical and Systems Engineering, Leicestershire LE11-3TU, UK

\section{Gilbert Shama}

Loughborough University, Department of Chemical Engineering, Leicestershire LE11-3TU, UK
\end{abstract}

The global burden of foodborne disease due to the presence of contaminating microorganisms remains high, despite some notable examples of their successful reduction in some instances. Globally, the number of species of micro-organisms responsible for foodborne diseases has increased over the past decades and as a result of the continued centralization of the food processing industry, outbreaks now have far reaching consequences. Gas plasmas offer a broad range of microbiocidal capabilities that could be exploited in the food industry and against which microbial resistance would be unlikely to occur. In addition to reducing the incidence of disease by acting on the microorganisms responsible for food spoilage, gas plasmas could also play a role in increasing the shelf-life of perishable foods and thereby reduce food wastage with positive financial and environmental implications. Treatment need not be confined to the food itself but could include food processing equipment and also the environment in which commercial food processing occurs. Moreover, gas plasmas could also be used to bring about the degradation of undesirable chemical compounds, such as allergens, toxins and pesticide residues, often encountered on foods and food-processing equipment. The literature on the application of gas plasmas to food treatment is beginning to reveal an appreciation that attention needs also to be paid to ensuring that the key quality attributes of foods are not significantly impaired as a result of treatment. A greater understanding of both the mechanisms by which micro-organisms and chemical compounds are inactivated, and of the plasma species responsible for this is forming. This is significant, as this knowledge can then be used to design plasma systems with tailored compositions that will achieve maximum efficacy. Better understanding of the underlying interactions will also enable the design and implementation of control strategies capable of minimizing variations in 
plasma treatment efficacy despite perturbations in environmental and operational conditions.

\section{INTRODUCTION}

In order to form a realistic and meaningful assessment of the potential that low temperature gas plasmas may have in the food industry, it is first necessary to provide a description of this particular sector and the factors that have shaped it in the recent past and determined its current form. Equally importantly, attention needs to be given to factors that have been identified as being likely to have an impact on its future.

The food industry in Western industrialized countries is increasingly becoming dominated by corporations with truly global reach. These are getting fewer in number through mergers and takeovers, and are therefore as a consequence becoming greater in size and influence. The principal advantage of this form of operation to the industry being of course, the classic one of economies of scale. However, as has been frequently pointed out, there are many aspects of the food industry which are not sustainable at a number of levels. For instance, it has become a major contributor to greenhouse gas (GHG) emissions, ${ }^{1}$ one instrumental factor in this being the elongation of the food distribution network. Freedman and Bess quote estimates suggesting that the 'average food item' travels some 1,500 miles before reaching the consumer's plate. ${ }^{2}$

Highly centralized food processing also presents increased risks in terms of the potential for causing food poisoning epidemics at national and even supra-national scales, both as a result of accidental and intentional contamination (i.e. bioterrorism). ${ }^{3}$ The consequences of centralization of food processing operations to a smaller number of large scale facilities may be illustrated by a multistate epidemic caused by a batch of peanut butter contaminated by Salmonella that was used in the manufacture of crackers by the Kellogg Corporation in the USA. ${ }^{4}$ Some 529 individuals in 43 states were rendered ill in 2008/2009 from this incident. Inevitably, the level of interdependence between these large food corporations is also growing, further increasing the risks. No example illustrates this better than the scandal which occurred in the UK in 2005 over the deliberate adulteration of chilli powder with the carcinogenic dye Sudan I in order to intensify its colour. The chilli powder was subsequently used in the formulation of a Worcester sauce condiment that itself came to be an ingredient in hundreds of individual food products.

Bacteria and viruses are the most common foodborne pathogens, accounting for $94 \%$ of the food poisoning cases in the USA, with the remainder attributed to both endogenous and exogenous chemical agents (5\% of all cases) and to parasites such as protozoa, roundworms, and tapeworms ( $1 \%$ of all cases). ${ }^{5}$ In terms of specific foodborne 
pathogens, however, national differences emerge and appear to be significant. For the years 1998-2010 Grass et al. cite Clostridium perfringens as the second most common bacterial cause (after Salmonella) of foodborne illness in the USA and responsible for some one million incidences of illness each year. ${ }^{6}$ Whereas in a survey of the burden caused by foodborne pathogens in the Netherlands for 2009 this particular bacterium does not feature at all. ${ }^{7}$ Instead, Toxoplasma gondii, Campylobacter spp., noroviruses, rotaviruses and Salmonella are named as the most prominent pathogens. By contrast in Taiwan, Vibrio parahaemolyticus, Staphylococcus aureus and Salmonella spp. head the list of the most common causative agents of foodborne disease. ${ }^{8}$ Whilst in the UK and the USA cases of Salmonella enterica ser. Enteritidis have been declining in the egg and poultry sector primarily as a result of the adoption of vaccination and other measures, ${ }^{5,9}$ outbreaks associated with leafy vegetables and dairy have increased. ${ }^{5}$

In order to make a significant impact towards reducing the burden of foodborne infections and disease, it would be both instructive and useful to consider what foods have emerged as being particularly susceptible as a consequence of the way in which they are produced and processed. Quested et al. claimed that meat and poultry were of 'central interest' to microbial food safety ${ }^{10}$ a pronouncement endorsed by Gould et al. who also found that poultry, fish and beef were the most common commodities implicated in foodborne illness. ${ }^{5}$ Fresh produce, whilst not contributing significantly to the burden of foodborne disease in England and Wales between 1996 and 2000 (from the data of Adak et al. ${ }^{11}$ ), is nonetheless causing international concern; ${ }^{10}$ with norovirus and leafy vegetables being identified as one of the most common pathogen-commodity pair in the USA between 1998 and 2008. Sprouted seeds described some 15 years ago as posing "international concern", ${ }^{12}$ continue to present a very real threat. ${ }^{13,14}$ Beansprouts, for example, were responsible for the $2011 \mathrm{E}$. coli O104:H4 outbreak that originated in Germany and spread across 16 countries in Europe and North America affecting thousands of people of which 50 died and resulting in costs measured in the hundreds of millions of dollars. ${ }^{15,16}$

The colonisation of foods by micro-organisms does not only pose health risks but also affects the shelf-life of the food itself. Fungi in particular are strongly implicated in food spoilage. This is a global problem ${ }^{17}$ and according to the Environmental Protection Agency (EPA) 34 million tonnes of food are wasted annually in the USA. ${ }^{18}$ In the UK, the Department for Environment, Food and Rural Affairs (DEFRA) estimates such losses amount to 7 million tonnes and the annual costs associated with avoidable food waste have been estimated as totalling $£ 12 \mathrm{bn} .{ }^{19}$ Besides the financial implications, food wastage also represents a needless consumption of finite resources such as water and energy, creates unnecessary GHG emissions and raises significant ethical questions in a world where starvation is not uncommon. 
Over the past two decades, research into novel non-thermal technologies having the capability to eliminate foodborne pathogens whilst overcoming the limitations of conventional high temperature and chemical approaches has intensified. Ultra high hydrostatic pressure processing, power ultrasound, pulsed electric fields, ozonation and irradiation have all been proposed. ${ }^{20}$ In this work we concentrate on the potential of lowtemperature plasmas. The use of plasmas in the food industry is an emerging field and one that is rapidly gathering momentum. This is evidenced by the numbers of publications that have appeared on the subject of food decontamination with plasmas over the last two decades (Figure 1).

\section{PLASMA SOURCES FOR FOOD TREATMENT}

A wide variety of plasma sources have been investigated in recent years for the treatment of biotic materials, including seeds, foods and animal/human tissue. These plasma sources differ greatly in the electrical operating conditions used to generate the plasmas, the gases in which these are created and result in discharges of different characteristics. They can, for example, be generated at low-pressures ${ }^{21,22,23,24}$ or at atmospheric pressure $^{25,26,27}$ (see also Table 1 and Table 2). They can be generated over a range of frequencies that includes line frequencies $(50 / 60 \mathrm{~Hz}),{ }^{26,28}$ low frequencies $(\mathrm{kHz}),{ }^{25,29}$ radio-frequencies $(\mathrm{MHz})^{27,37}$ and microwave frequencies $(\mathrm{GHz}) .^{24,30,31}$ Although in most instances the electric fields are coupled capacitively, use has also been made of inductively coupled plasmas. ${ }^{21,32}$ The types of discharges obtained can vary from gliding arcs, ${ }^{29,33}$ surface discharges, ${ }^{34}$ volumetric discharges ${ }^{26,31}$ to plasma jets. ${ }^{25,35}$ They can be operated in air ${ }^{26,31}$ or other mixtures of gases. ${ }^{21,25}$ All of these plasma systems have demonstrated antimicrobial properties against a broad range of micro-organisms, including Gram-positive bacteria, Gram-negative bacteria, antibiotic resistant bacteria ${ }^{36}$, viruses $^{37}$ and fungi. ${ }^{25}$ They have also been shown to inactivate both bacterial and fungal spores, ${ }^{38}$ as well as micro-organisms existing within biofilms. ${ }^{39}$

The broad-spectrum antimicrobial capability that gas plasmas possess should make them of particular interest to the food industry, as a single technology could be used to counter the threat posed by both foodborne pathogens and spoilage micro-organisms. In contrast to chemical-based technologies, plasmas can be created in environmentally friendly gases, including air, thus minimizing the environmental burden of the technology, and given their broad range of antimicrobial agents it makes it difficult for bacteria to develop resistance. $^{40}$

Many of the pioneering studies reported in the literature have used plasma sources initially conceived for other applications (e.g. semiconductor processing). Notwithstanding the bactericidal properties such plasmas may possess, some of these designs suffer important limitations when it comes to implementation in practical 
scenarios within the food industry. Arguably, the ideal plasma source for food processing would (1) operate at atmospheric pressure to avoid the need for expensive vacuum equipment thus enabling rapid continuous in-line food processing, and (2) operate in air to avoid the inconvenience and cost of having to supply specific gases. As shown in Table 1 and Table 2, there exist a number of different systems that operate at atmospheric pressure in air. Although other technologies exist, the most common technology used to generate low-temperature (i.e. close to room temperature) atmospheric-pressure plasmas in air is the dielectric barrier discharge (DBD). DBDs have been known for more than a century and they are widely used in many industrial applications such as in ozone generators and in plasma display panels. ${ }^{41}$ Figure 2 shows schematics of surface, volumetric and jet dielectric barrier discharges that have been used for treating food. Surface discharges, as their name suggests, generate plasma on the surface of the dielectric, and therefore result in an indirect treatment of the food, i.e. the food is exposed only to UV light and reactive species generated in the plasma that are able to travel from the discharge itself to the food. In this type of indirect treatment, both charged species and short-lived reactive species are mainly confined to the surroundings of the dielectric and do not reach the food under treatment. On the other hand, in volumetric plasma discharges, the electrodes are separated in such a way that the plasma forms in a cavity created in between the electrodes (Figure 2b). Food placed in this cavity would be in direct contact with the plasma, which tends to attach to the food surface. Volumetric discharges, therefore, result in a closer interaction between the plasma and the food, and in this case all the species generated in the plasma are likely to be involved in the treatment. Depending on the discharge conditions, this close interaction may not be beneficial and can lead to non-uniform treatment of the food or excessive localized heating, and therefore in some cases it is preferable that the food be indirectly exposed to the plasma by placing it adjacent rather than inside the volumetric discharge. In jet discharges, both direct and indirect treatments are possible, depending on the electrode arrangement and distance between the jet nozzle and the food under treatment. Jets provide a means of delivering a localized treatment and they typically rely on the flow of noble gases (typically He or Ar) to create a discharge channel or plume in which to the plasma forms and the precursors of reactive species (e.g. $\mathrm{O}_{2}$ ) are either added as admixtures in the feed gas or mixed directly into the plasma plume.

\section{A. Direct Food Treatment}

Plasmas have been used to inactivate micro-organisms on seeds, grain and legumes, ${ }^{24,32,31}$ plant-derived foods (see Table 1) as well as dairy products and meat (see Table 2). It is clear from the data shown in Table 1 and Table 2 that the efficacy of the plasma systems in reducing the number of viable micro-organisms varies substantially from system to system, but these systems typically achieve 1 to 5 log reductions after plasma treatments 
of 0.5-15 minute duration. To match the processing times typical of the food industry, which can be of the order of one item per second, plasma systems would need to be engineered to be applied in tunnels of suitable length, or at a stage in the processing line at which the effect of plasma treatment can be sustained beyond the actual plasma exposure (e.g. post packaging).Part of the variability observed in the data presented in Tables 1 and 2 can be attributed to the inherent variability of biological matter, a challenge which would have to be met were plasmas to be employed in real applications. For experiments aimed at unravelling the mechanisms governing the interaction between bacteria and plasmas, careful preparation and elaborate protocols have been developed to yield well characterized microbial populations, ${ }^{42,43}$ and a number of valuable insights regarding the interaction between plasmas and bacteria have been obtained in recent years with carefully designed experiments. ${ }^{44,45,46,47}$ Attempts to extrapolate the efficacy of plasmas from carefully controlled lab experiments to that of the processing of foods would need to be done with care as variations in the condition of the substrate (i.e. the food) and the microbial population would have an impact on the overall performance of the system. The surfaces of real foods would typically be far more complex than that of the model system most frequently resorted to and comprising agar in a petri dish onto which microorganisms have been deposited. The surface topography of foods provides crevices and other surface features in which bacteria might be protected from the impacts of plasma, or indeed other, microbiocidal treatments. ${ }^{109}$ Studies in which foodstuffs are artificially contaminated with the appropriate microorganisms are evidently more realistic, but even in such cases it would be difficult to emulate exactly the true circumstances by which foods become contaminated, and this would affect the physical condition of microorganisms at the surface and ultimately their survival. In addition the microorganisms may express different phenotypes which are determined by their environment. In short, the difficulty of creating accurate microbiological models is not confined to studies involving gas plasmas and is a common factor in the evaluation of food decontamination technologies.

\section{B. Food Packaging and Food Processing Equipment}

Packaging of all kinds provides a barrier between a particular food and the environment and should serve to prevent its contamination by organisms from the environment. Gas plasmas have been shown to sanitize packaging polymer foils, ${ }^{48}$ aluminium foils, plastic trays and paper cups ${ }^{49}$ and polyethylene terephthalate bottles. ${ }^{50}$ Besides providing a barrier to prevent contamination, packaging also offers the possibility to control the environment in which a food is preserved. ${ }^{51}$ For example $\mathrm{N}_{2}$ - and $\mathrm{CO}_{2}$ - rich atmospheres are often used to package fruits and vegetables in order to reduce the amount of $\mathrm{O}_{2}$ and ethylene levels, thereby slowing down both the growth of aerobic micro-organisms and the extent of ripening. Similarly, other gases such as CO are used to preserve the red 
colour of meat. Prevention of spoilage in packaged food by means of a modified atmosphere does not necessarily prevent the growth of other potentially dangerous pathogens such as anaerobes. ${ }^{52}$ In this context, plasma treatment of food in-package is a very promising development as the bactericidal properties of the plasma are delivered to both aerobic and anaerobic micro-organisms. Being already packaged, once the food is treated the chances of it becoming contaminated are greatly reduced. ${ }^{26,53,54}$

\section{Performance Variability}

There exists large variability in terms of the efficacy of plasma treatments (see Table 1 and Table 2), even among apparently very similar plasma systems. As discussed above, the biological nature of the application would undoubtedly introduce a substantial element of variability. Variability, however, is not confined solely to the biological 'target' itself; both the environment and the plasma system also contribute to this. For example, dielectric barrier discharges may operate in a non-uniform mode - even in a chaotic manner $-{ }^{55}$ making it difficult to guarantee repeatability of treatments even with the same plasma system. As many of these devices operate in open air, environmental variations (e.g. temperature, relative humidity, air currents) can also affect the resulting plasma chemistry and its delivery. The amount of power delivered to a plasma is also sometimes hard to determine and control accurately, particularly in high frequency systems. Furthermore, depending on the design of the power supply, subtle variations in so called parasitic capacitances caused by the presence of food undergoing treatment can affect the intensity of the discharge and hence the temperature and plasma composition.

As an example, Figure 3 shows the amount of ozone generated by an atmospheric-air dielectric surface discharge in an enclosed chamber as a function of the operating frequency. The plasma is driven by a half-bridge resonant power supply, a supply with a topology in which the output voltage depends on the frequency of operation. The ozone was measured using UV absorption spectroscopy at 260nm. It can be seen from the figure that the amount of ozone generated by the plasma depends non-linearly on the frequency of operation (only data above the resonant frequency is shown as this is the preferred regime of operation for such power supplies, ${ }^{56}$ and that fairly small frequency variations can bring about significant variations in the amount of ozone being produced. A combination of factors is responsible for the observed variation of ozone concentration. Firstly, as the frequency is changed the plasma source can become either tuned or detuned, and therefore the voltage applied to the plasma varies. This in turn affects the power delivered to the discharge and hence the discharge temperature. Since the stability of ozone is strongly temperature-dependent, ${ }^{41}$ the resulting changes in temperature affect ozone production and therefore higher ozone concentrations are obtained when the discharge is operated above the resonant frequency as the discharge is then less intense and cooler than at resonance. The frequency of operation for optimum ozone production 
would also depend on the duty cycle employed, as larger duty cycles result in greater heat generation for a given frequency of operation. Although ozone concentrations are given in Figure 3a, variations in other plasma-derived reactive species are also likely to occur with the frequency of operation and hence, small changes in the latter can bring about significant changes in plasma composition and treatment efficacy.

Furthermore, the amount of ozone present in the treatment chamber also depends on the humidity in the chamber ${ }^{41}$ and the presence or absence of biological matter, as this would have a quenching effect on the ozone. Figure 3b shows the amount of ozone under loaded (i.e. with biological matter present) and unloaded (i.e. without biological matter) conditions for an enclosure in which a surface dielectric barrier discharge is operated. The figure shows that the presence of biological matter in the system can be quite important, and hence inactivation results will strongly depend not only on the microorganisms, the environment and the discharge conditions, but also on the surface area and composition of the food being treated. As a result, plasma systems intended for the food industry would require feedback loops to provide reliable plasma treatment.

\section{UNDERLYING PHYSICO-CHEMICAL MECHANISMS}

The underlying physico-chemical mechanisms that govern the interaction of gas plasmas and cells have been actively investigated in recent years, primarily in the rapidly developing field of plasma medicine. ${ }^{57,58,59}$ Gas plasmas comprise complex mixtures of charged species, reactive species, and photons and all of these can contribute to the triggering of the elicited biological responses. In addition, synergistic effects are also possible. It is well-known, for example, that chemical etching can be enhanced by ion bombardment, resulting in etching rates much superior to those achieved separately by either chemical and physical processes. ${ }^{60}$ Similarly, heat and UV radiation were found to interplay synergistically in the inactivation of bacteria in a $\mathrm{N}_{2} / \mathrm{O}_{2}$ afterglow plasma. ${ }^{46}$

Early attempts to infer the nature of the lethal effects gas plasmas were exerting against micro-organisms were based upon an analysis of the form of inactivation curves which are usually plotted in the form of the logarithm of survivors against time. ${ }^{61}$ These curves are rarely monotonic and display two, or sometimes three, distinct phases. These accounts came to be supplemented by evidence gained from the examination of SEM images - most commonly of spores. ${ }^{62}$ Insightful though these interpretations were, they could not be taken as providing definitive explanations in all cases of the effects of exposure of different types of micro-organism to gas plasmas.

It is now broadly accepted that in low-pressure systems UV radiation and ion bombardment play a very significant role in the inactivation process of micro-organisms, these being instrumental in DNA damage and physical etching of the cell membranes. ${ }^{45,63}$ 
At atmospheric pressure, however, ions are less energetic due to the increased collisionality against the background gas molecules and therefore physical etching due to ion bombardment is normally believed not to be significant in such plasmas. Regarding the role of UV radiation in atmospheric pressure plasmas, different results have been observed by different research groups. In some instances, UV is found to have a negligible effect when viewed against the overall microbiocidal properties of the plasma. ${ }^{44}$ This, however, would depend on the system under consideration since the wavelength and intensity of the UV radiation produced by the plasma depends strongly on the gas composition.

Perni et al. adopted a more direct approach to unravel the physico-chemical processes underpinning the microbiocidal effects of plasmas by making use of mutants of $E$. coli deficient in particular genes. ${ }^{64}$ By this method it was established that oxygen atoms were primarily responsible for cell inactivation; there being only minor contributions from UV photons, $\mathrm{OH}$ radicals and nitric oxide. More recently using an identical approach, Judee et al. concurred that cell inactivation occurred primarily as a result of UV photons. ${ }^{65}$ This apparently contradicting result can be attributed both to differences in the methods used to produce the gas plasmas $\left(\mathrm{He} / \mathrm{O}_{2} 43.5 \mathrm{kHz}\right.$ jet vs Ar microwave $2.45 \mathrm{GHz}$ jet), and to the state of the target organism - E. coli. In the latter study cells were in suspension, whereas in that of Perni et al the cells were in a drier state having been deposited onto the surface of filter membranes.

For most atmospheric pressure discharges, however, plasma chemistry is believed to play a key role. Although attention was primarily focused on reactive oxygen species (ROS), consideration is now turning towards reactive nitrogen species (RNS). The important biological role of these species has recently been extensively and systematically reviewed by Graves. ${ }^{66}$ Typical ROS and RNS species that can be generated in these plasmas include $\mathrm{O}, \mathrm{O}_{3}, \mathrm{OH}, \mathrm{H}_{2} \mathrm{O}_{2}, \mathrm{H}_{2} \mathrm{O}, \mathrm{NO}, \mathrm{NO}_{2}, \mathrm{~N}_{2} \mathrm{O}_{5}, \mathrm{~N}_{2} \mathrm{O},{ }^{67,68,69}$ most of which are chemical species known to interact with living matter and have been studied by the free radical biology community. ${ }^{70}$ The actual ROS/RNS cocktail composition would depend on the background gas mixture, the electron temperature and the gas temperature of the discharge. For example, low temperature plasmas with low electron temperature and reasonable air circulation, will favour ozone production over $\mathrm{NO}_{\mathrm{x}}$.

The cell membrane was generally considered to be the primary target which suffered damage following exposure to gas plasmas leading to loss of integrity and ultimately cell death, ${ }^{44}$ however, microarray analysis of plasma-treated $E$. coli cells revealed a process involving the oxidative stress response, which suggested the presence of ROS inside the cell and implied that there were cellular targets other than the cell membrane. ${ }^{71} \mathrm{~A}$ recent review by Lackman and Bandow paints a far more complex picture involving not only 
disruption of the cell membrane but also etching of the cell wall, DNA damage, RNA strand breaks and oxidative damage to proteins. $^{72}$

Although reactive plasma species can interact with biomolecules and micro-organisms directly, in most practical scenarios this interaction is mediated by fluids and extracellular matrices. This has been recognized in recent years and significant steps are being taken to identify chemical species forming in this intermediate medium as a result of reactive plasma species. These intermediate chemical species, often referred to as 'secondary chemistries', ${ }^{73,74,75}$ would be the ones that convey the plasma effects beyond the interface of the medium and the plasma, as the highly reactive plasma species are rapidly lost at that interface. $^{76,77}$

\section{BEYOND MICROBIAL INACTIVATION}

Whereas the primary goal in the treatment of foods with gas plasmas has largely been one of bringing about the inactivation of micro-organisms that have come to contaminate them, there is no doubt that chemical species generated by the plasma also react with the food under treatment (see for example the quenching of ozone produced by the presence of food in Figure 3b). Therefore, foodborne microbial inactivation cannot be undertaken without consideration of what other impacts (whether positive or negative) plasma treatment would have on the food.

\section{A. Food Quality}

The earliest accounts of the use of gas plasmas to treat foods tended to neglect the impact of treatment on the quality of the treated food. Such considerations, however, are of critical importance as anything that impacts negatively on the appearance, taste or nutritional value of a food will affect its saleability. Although quantitative information remains limited, it is generally accepted that direct plasma treatments are more aggressive and can cause deleterious effects in shorter periods of time than indirect treatments. Both treatments, however, will have a negative impact on the quality of the treated food if they are applied for too long. The importance of assessing changes in the quality of the treated food has gradually come to be accepted, and recently published studies provide accounts, alongside those on log reductions of microbial burden, of the effects of treatment on various food quality attributes.

An early evaluation of the impacts of treatment was that conducted by Vleugels et al. who showed that the treatment of bell peppers did not affect their colour following treatment with gas plasmas. ${ }^{39}$ Similar findings have been found for a wide variety of different foodstuffs. Although prolonged exposure to plasma will eventually bleach the colour of foods due to the oxidative nature of the plasma chemistry, it has proved possible to find a window of operation in which plasma treatment is applied for a time 
sufficient for the plasma to exert its antimicrobial properties but not too long as to damage the visual appearance of the food under treatment. Operation of a variety of different types of plasma sources have resulted in only small differences in colour in plasma treated lettuce, strawberries, pork, tomatoes and peppers. ${ }^{28,39,78,79,80,81}$ Interestingly, plasma treatment of fresh cut apples can delay the browning of the fruit for periods of up to 4 hours following a 15 minute plasma exposure. Although oxidation brings about the natural browning of fruit, the oxidative environments created within the plasma served primarily to inactivate the enzymes responsible for enzymatic browning. ${ }^{78}$

Besides food colour, the texture and firmness of the product constitute another important quality attribute. Here again, under controlled plasma exposure, no statistically significant difference was found between treated and untreated samples of strawberries, cherry tomatoes or apples. ${ }^{78,80,81}$

Numerous studies have confirmed that plasma treatments bring about $\mathrm{pH}$ changes. It is well documented, for example, that air plasma treatment of water results in an acidified medium having antimicrobial properties. ${ }^{74,82,83}$ The extent of acidification depends on the composition of the plasma (in particular the amounts of nitrous and nitric acids produced in an air plasma via $\mathrm{NO}$ and $\mathrm{NO}_{2}$ ) and the buffering capacity of the medium being treated. When measuring the $\mathrm{pH}$ of treated and untreated cherry tomatoes, Misra et al found no significant $\mathrm{pH}$ difference. ${ }^{81}$ On the other hand, when treating pork samples, Frohling et al found that plasma exposure resulted in the acidification of the samples. ${ }^{79,81}$ Such acidification, however, is likely to be confined to the surface of the food undergoing treatment as $\mathrm{pH}$ measurements of homogenized plasma-treated pork samples do not show pH changes. ${ }^{27}$

A relatively recent strategy for increasing the shelf life of fresh produce has been to subject it to a sub-lethal physical stress that induces a reaction in the produce that is protective. This phenomenon is known as "hormesis." A number of physical treatments such as dipping in hot water ${ }^{84}$ and UV irradiation ${ }^{85}$ have been investigated and although plasmas have the potential to influence metabolic pathways in fresh foods, ${ }^{78}$ to date hormetic responses to plasma treatments have not been investigated. The application of hormetic treatment would require careful design to enable it to be incorporated into existing processes and procedures ${ }^{86}$ and thought should be given to the use of gas plasmas in this regard.

\section{B. Degradation of Allergens, Toxins and Pesticide Residues}

There is evidence to suggest that the incidence of food-related allergies has increased during the last 10 to 20 years. ${ }^{87}$ This has had consequences for the food processing industry which increasingly needs to ensure that foods that do not induce allergenic reactions do not become contaminated by allergens from foods, such as nuts, dairy 
products and gluten-containing foods that have become associated with the rising tide of allergies caused by foods. The need to avoid cross contamination necessitates having multiple production lines that are used exclusively for only one type of food, or alternatively, require the rigorous cleaning and decontamination of food processing equipment which typically results in a large water usage along with cleaning agents. ${ }^{88}$

Food allergens are primarily proteins, and there is evidence that gas plasmas possess the ability to remove proteins that are tightly attached to solid surfaces. ${ }^{45,89}$ Prior to this, Shintani et al. demonstrated effective removal of a protein endotoxin of bacterial origin from the surface of polystyrene using gas plasma, ${ }^{90}$ and more recently Sakudo et al. characterised changes to proteins deposited onto solid materials. ${ }^{37}$ Although these authors were not investigating allergenicity, the conformational changes observed in the proteins studied were such as to suggest that treatment of surface-associated allergens could result in a significant reduction of the power of allergens to bring about their various reactions. However, there have as yet been no published accounts dealing specifically with the action of gas plasmas against adsorbed allergens, and this is clearly an area meriting investigation.

Gas plasmas have also been shown to be effective in reducing the concentration of the highly carcinogenic aflatoxin in nuts colonized by Aspergillus flavus. ${ }^{21,91}$ A number of foodborne micro-organisms produce heat-stable toxins that survive cooking ${ }^{92}$ and there would be value in establishing whether gas plasmas could degrade such toxins.

Agricultural and horticultural production of crops has become dependent on the use of a variety of pesticides. Residues of the agents used for eliminating insects and fungi inevitably come to contaminate the produce treated with them, and there is rising concern about the possible effects on human health by the consumption of produce treated in this way. ${ }^{93}$ When viewed alongside initiatives to promote increased consumption of fresh fruit and vegetables on health grounds, the potential for impact on human health could become significant, and therefore some means of decontaminating this category of foods is urgently required pending the development of strategies for developing alternative agents which are effective against their intended targets whilst posing no threat to health if consumed. Application of gas plasmas for the purposes of reducing pesticide burden has started to be investigated and has yielded some promising results. ${ }^{94,95,96}$ Recently, Misra et al. reported degradation of pesticide residues on the in-package treatment of fresh produce. $^{26}$

\section{The Food Processing Environment}

Certain types of food processing operations are associated with the production of offensive odours which can become the causes of complaints by residents living in the vicinity of such processing facilities. One such operation is the rendering of meat. ${ }^{97}$ 
However, there do not appear to have been studies undertaken on odour control using gas plasmas with specific reference to the food industry. This is despite the fact that the technology has already been applied for the abatement of odours in commercial animal houses ${ }^{98,99}$ and in pesticide-producing facilities ${ }^{100}$ to name just two, and therefore could readily be applied in the food industry.

\section{CONCLUSIONS AND FUTURE OUTLOOK}

An analysis of trends in the emergence of foodborne pathogens over the last 50 years by Newell et al. reveals a disturbing pattern and one that literally bodes ill for the future (Figure 4). ${ }^{101}$ This is testimony that the technologies currently available for ensuring microbial food safety have failed to keep up with the changes that have taken place over this period of time in the way that food is produced, distributed, retailed and even, eaten. ${ }^{10}$ Not only has the number of foodborne pathogens increased over the years, but as a result of the continued centralization of the food processing industry, outbreaks have ever increasing consequences.

Changes made to the formulation of food recipes on health grounds such as reducing the salt and sugar contents of certain could well have unforeseen consequences for food safety as this would result in the removal of the protective effects that they provide (i.e. lowering of water activity and specific solute effects). ${ }^{102}$ Moreover, the measures previously referred to which are designed to encourage increased consumption of fresh produce could backfire if the contribution to foodborne disease by fresh produce continues to increase. Demographic changes will also have implications for food safety as most illnesses affect elderly populations to a greater extend. ${ }^{103}$ For example, listeriosis in the USA had an average fatality rate of $21 \%$ in 2011 but for those aged over 65 this rose to $58 \%{ }^{13}$

In any event, attention certainly needs to be devoted to the foods that are most heavily implicated in the causation of foodborne disease. The consensus of opinion is that included in this category is meat and sprouted seeds. The increase in incidents of foodborne illness resulting from the consumption of fresh produce is also one that needs addressing, particularly as a number of agencies are promoting increased consumption of fresh fruit and vegetables for the benefits they provide to human health. Beside the inactivation of foodborne pathogens, plasmas can also inactivate spoilage microorganisms, thereby contributing to reducing food waste.

It would be unrealistic to assume that a single technology could bring about a reversal in the trend revealed by Figure 4, however, the introduction of gas plasmas at strategic points in the process that starts at the farm and ends at the fork could, along with other interventions, at the very least bring about a mitigation of the situation. Various scenarios 
can be envisaged in which plasma treatment of foods and food processing equipment could be introduced to increase the safety of processed foods. Direct treatment of foods, e.g. fresh fruits and vegetables, as well as treatment of packaged food (e.g. wrapped chickens) and in-package food (e.g. prepared salads) are all feasible. In a processing plant, throughput as well as absence of deleterious effects would be important design considerations aspects that were overlooked in early studies but that are slowly being addressed by the community. Food processing equipment (e.g. conveyor belts or equipment used for slicing foods) constitute a less demanding application than the food itself as in this case, the plasma could be permitted to reach temperature and conditions that would be deleterious to food but that would be tolerated by equipment.

There is a huge diversity in the types of gas plasmas that have been employed to investigate microbial inactivation and it is difficult, if not impossible, to compare results from different sources, even when identical species of micro-organism have been employed. In order to enable valid comparisons of plasma microbiocidal efficacy, adoption of a universally agreed microbiological standard, for example spores of Bacillus subtilis prepared according to carefully laid out protocols, would alleviate this problem. ${ }^{43}$ The variability reported in the literature, however, is not only attributable to statistical changes in biological matter but it also reflects the influences of environment and discharge operating conditions. It would be possible, however, to engineer control systems to mitigate the effects of these environmental changes and improve the repeatability of the plasma treatment to a level acceptable for use in an industrial setting.

Besides the microbiocidal effect, plasmas can also potentially be used to degrade allergens, toxins and pesticide residues on foods. Further understanding of the underlying mechanisms, identification of degradation products and assessment of biochemical changes in the food itself are, however, required before the technology can be safely applied by the food industry. Whilst this work has considered the food industry at large scale, there is also scope for small scale de-centralized processing units as, for example, substantial cumulative amount of food waste occurs at lower scales of food preparation ranging from institutional kitchens and restaurants. Could gas plasmas have a role to play in the home?

\section{ACKNOWLEDGMENTS}

This work was supported by the UK Engineering and Physical Science Research Council (EPSRC). 


\section{TABLES}

Table 1 Air-based Gas Plasma Treatment of Plant-derived Foods

\begin{tabular}{|c|c|c|c|c|}
\hline Foodstuff & Targeted micro-organisms & Effects of treatment & Plasma treatment & Ref \\
\hline Almonds & E. coli & $\begin{array}{l}5 \text { log reductions after } 30 \\
\text { seconds }\end{array}$ & $\begin{array}{l}\text { - } 25 \mathrm{kV}, 1-2.5 \mathrm{kHz} \\
\text { - Volumetric DBD } \\
\text { - Direct } \\
\text { - Air, in chamber }\end{array}$ & 33 \\
\hline Almonds & E. coli 0157:H7 & $\begin{array}{l}1.3 \text { log reductions after } 20 \\
\text { seconds }\end{array}$ & $\begin{array}{l}\text { - } 549 \mathrm{~W}, 47 \mathrm{kHz} \\
\text { - } \text { Jet } \\
\text { - } \text { Direct } \\
\text { - } \text { Dry air or } \mathrm{N}_{2}\end{array}$ & 29 \\
\hline Apples & Salmonella Stanley & $\begin{array}{l}2.4 \text { to } 3.7 \text { log reductions } \\
\text { after } 3 \text { minutes } \\
2.6 \text { to } 3 \text { log reductions after } \\
3 \text { minutes }\end{array}$ & $\begin{array}{l}\text { - } 15 \mathrm{kV}, 60 \mathrm{~mA}, 60 \mathrm{~Hz} \\
\text { - } \text { Gliding arc } \\
\text { - Indirect } \\
\text { - } \text { Air }\end{array}$ & 104 \\
\hline \multirow[t]{2}{*}{ Apples } & $\begin{array}{l}\text { E. coli O157:H7 (four } \\
\text { strain cocktail) } \\
\text { Salmonella (five strain } \\
\text { cocktail) }\end{array}$ & $\begin{array}{l}>2 \text { log reductions after } 2 \\
\text { minutes } \\
>2 \text { log reductions after } 1 \\
\text { minutes }\end{array}$ & $\begin{array}{l}\text { - } 9 \mathrm{kV}, 6 \mathrm{kHz} \\
\text { - Volumetric DBD } \\
\text { - Indirect } \\
\text { - In chamber }\end{array}$ & 105 \\
\hline & $\begin{array}{l}\text { Listeria monocytogenes } \\
\text { (five strain cocktail) }\end{array}$ & $\begin{array}{l}1 \text { log reduction after } 1 \\
\text { minute }\end{array}$ & & \\
\hline Lettuce & $\begin{array}{l}\text { E. coli 0157:H7 (four } \\
\text { strain cocktail) } \\
\text { Salmonella (five strain } \\
\text { cocktail) }\end{array}$ & $\begin{array}{l}>3 \text { log reductions after } 3 \\
\text { minutes } \\
>5 \text { log reductions after } 5 \\
\text { minutes }\end{array}$ & $\begin{array}{l}\text { - } 9 \mathrm{kV}, 6 \mathrm{kHz} \\
\text { - } \text { Volumetric DBD } \\
\text { - Indirect } \\
\text { - In chamber }\end{array}$ & 105 \\
\hline Lettuce & Salmonella Typhimurium & $\begin{array}{l}2.7 \text { log reductions after } 15 \\
\text { minutes }\end{array}$ & $\begin{array}{ll}\text { - } & 1 \mathrm{~W}, 1 \mathrm{kHz} \\
\text { - } & \text { Jet } \\
\text { - } & \text { Indirect } \\
\text { - } & \mathrm{N}_{2}\end{array}$ & 106 \\
\hline Lettuce & E. coli & $\begin{array}{l}1.7 \text { log reductions after } 10 \\
\text { minutes }\end{array}$ & $\begin{array}{l}\text { - } 3.95 \text { to } 12.83 \mathrm{kV} \text {, } \\
60 \mathrm{~Hz} \\
\text { - } \text { Needle array to } \\
\text { mesh } \\
\text { - Indirect } \\
\text { - } \mathrm{Ar}\end{array}$ & 28 \\
\hline Lettuce & E. coli & $\begin{array}{l}\text { 3.6 log reductions after } 15 \\
\text { seconds (low bacterial load) } \\
\text { and } 2.1 \text { log reductions after } \\
30 \text { seconds (high bacterial } \\
\text { load) }\end{array}$ & $\begin{array}{l}\text { - } 27.12 \mathrm{MHz}, 10-40 \mathrm{~W} \\
\text { - } \text { Jet } \\
\text { - } \text { Indirect } \\
\text { - } \mathrm{Ar}\end{array}$ & 107 \\
\hline
\end{tabular}




\begin{tabular}{|c|c|c|c|c|}
\hline \multirow[t]{3}{*}{ Mango } & Listeria monocytogenes & $\begin{array}{l}2.5 \text { log reductions after } 30 \\
\text { seconds } \\
2.5 \text { log reductions after } 30 \\
\text { seconds }\end{array}$ & $\begin{array}{l}\text { - } 8 \mathrm{kV}, 30 \mathrm{kHz} \\
\text { - Jet } \\
\text { - } \text { Direct } \\
\text { - } \mathrm{He} \text { and } \mathrm{O}_{2}\end{array}$ & 25 \\
\hline & Saccharomyces cerevisiae & $\begin{array}{l}2.5 \text { log reductions after } 40 \\
\text { seconds }\end{array}$ & & \\
\hline & $\begin{array}{l}\text { Gluconobacter } \\
\text { liquefaciens }\end{array}$ & $\begin{array}{l}2 \text { log reductions after } 10 \\
\text { seconds }\end{array}$ & & \\
\hline $\begin{array}{l}\text { Melon } \\
\text { (Cantaloupe) }\end{array}$ & $\begin{array}{l}\text { E. coli } \\
\text { Listeria monocytogenes } \\
\text { Saccharomyces cerevisiae } \\
\text { Gluconobacter } \\
\text { liquefaciens }\end{array}$ & $\begin{array}{l}1.5 \log \text { reductions after } 40 \mathrm{~s} . \\
2 \log \text { reductions after } 40 \mathrm{~s} . \\
1 \text { log reductions after } 40 \mathrm{~s} . \\
2 \log \text { reductions after } 10 \mathrm{~s} .\end{array}$ & $\begin{array}{l}\text { - } 8 \mathrm{kV}, 30 \mathrm{kHz} \\
\text { - Jet } \\
\text { - } \text { Direct } \\
\text { - } \mathrm{He} \text { and } \mathrm{O}_{2}\end{array}$ & 25 \\
\hline $\begin{array}{l}\text { Melon } \\
\text { (Cantaloupe) }\end{array}$ & $\begin{array}{l}\text { E. coli O157:H7 (four } \\
\text { strain cocktail) } \\
\text { Salmonella (five strain } \\
\text { cocktail) }\end{array}$ & $\begin{array}{l}>3 \text { log reductions after } 3 \\
\text { minutes } \\
>5 \text { log reductions after } 5 \\
\text { minutes }\end{array}$ & $\begin{array}{l}\text { - } 9 \mathrm{kV}, 6 \mathrm{kHz} \\
\text { - Volumetric DBD } \\
\text { - Indirect } \\
\text { - In chamber }\end{array}$ & 105 \\
\hline Potatoes & Salmonella Typhimurium & $\begin{array}{l}0.9 \text { log reductions after } 15 \\
\text { minutes }\end{array}$ & $\begin{array}{l}\text { - } 1 \mathrm{~W}, 1 \mathrm{kHz} \\
\text { - } \quad \text { Jet } \\
\text { - } \text { Indirect } \\
\text { - } \mathrm{N}_{2}\end{array}$ & 106 \\
\hline Strawberries & Salmonella Typhimurium & $\begin{array}{l}1.8 \text { log reductions after } 15 \\
\text { minutes }\end{array}$ & $\begin{array}{l}\text { - } 1 \mathrm{~W}, 1 \mathrm{kHz} \\
\text { - Jet } \\
\text { - Indirect } \\
\text { - } \mathrm{N}_{2}\end{array}$ & 106 \\
\hline Strawberries & Natural microflora & $\begin{array}{l}\sim 3.0 \text { log reductions after } 5 \\
\text { minutes }\end{array}$ & $\begin{array}{l}\text { - } 60 \mathrm{kV}, 50 \mathrm{~Hz} \\
\text { - Volumetric } \mathrm{DBD} \\
\text { - Indirect } \\
\text { - In package } \\
\text { - } \mathrm{O}_{2}, \mathrm{~N}_{2} \text { and } \mathrm{CO}_{2} \text { or } \mathrm{N}_{2} \\
\text { and } \mathrm{O}_{2}\end{array}$ & 26 \\
\hline Tomatoes & E. coli & $\begin{array}{l}1.7 \text { log reductions after } 10 \\
\text { minutes }\end{array}$ & $\begin{array}{l}\text { - } 3.95 \text { to } 12 \mathrm{kV}, 60 \mathrm{~Hz} \\
\text { - } \text { Needle array to } \\
\text { mesh } \\
\text { - Indirect } \\
\text { - } \mathrm{Ar}\end{array}$ & 28 \\
\hline \multirow[t]{2}{*}{$\begin{array}{l}\text { Tomatoes } \\
\text { (Cherry) }\end{array}$} & E. coli & $\begin{array}{l}3.1 \text { log reductions after } 10 \\
\text { seconds }\end{array}$ & $\begin{array}{ll}\text { - } & 70 \mathrm{kV}, 50 \mathrm{~Hz} \\
\text { - } & \text { Volumetric DBD } \\
\text { - } & \text { Indirect }\end{array}$ & 53 \\
\hline & Salmonella Typhimurium & $\begin{array}{l}6.3 \text { log reductions after } 60 \\
\text { seconds }\end{array}$ & - Air & \\
\hline
\end{tabular}


Table 2. Air-based Gas Plasma Treatment of Dairy Products and Meat

\begin{tabular}{|c|c|c|c|c|}
\hline Foodstuff & Targeted Micro-organisms & $\begin{array}{l}\text { Effects of } \\
\text { Treatment }\end{array}$ & Plasma treatment & Ref \\
\hline Bacon & $\begin{array}{l}\text { Listeria monocytogenes } \\
\text { Salmonella Typhimurium } \\
\text { E. coli }\end{array}$ & $\begin{array}{l}\text { 4.6 log reductions after } \\
1.5 \text { minutes } \\
\text { (results reported as 'total } \\
\text { aerobic counts') }\end{array}$ & $\begin{array}{l}\text { - } 75-125 \mathrm{~W} \\
\text { 13.56MHz } \\
\text { - } \text { Volumetric DBD } \\
\text { - } \text { Direct } \\
\text { - } \mathrm{He}\end{array}$ & 27 \\
\hline $\begin{array}{l}\text { Cheese } \\
\text { (sliced) }\end{array}$ & $\begin{array}{l}\text { Listeria monocytogenes ( } 3 \text { strain } \\
\text { cocktail) }\end{array}$ & $\begin{array}{l}>8 \text { log reductions after } 2 \\
\text { minutes }\end{array}$ & $\begin{array}{l}\text { - } 75 \text { to } 125 \mathrm{~W} \text {, } \\
13.56 \mathrm{Mhz} \\
\text { - Volumetric DBD } \\
\text { - Direct } \\
\text { - } \text { He and } \mathrm{O}_{2}\end{array}$ & 108 \\
\hline $\begin{array}{l}\text { Chicken } \\
\text { (raw) }\end{array}$ & Listeria innocua & $\begin{array}{l}>3 \text { log reductions after } 4 \\
\text { minutes }\end{array}$ & $\begin{array}{l}\text { - } 6.5 \text { to } 16 \mathrm{kV}, 23 \\
\text { to } 38.5 \mathrm{kHz} \\
\text { - Jet } \\
\text { - Direct } \\
\text { - He and } \mathrm{O}_{2}\end{array}$ & 109 \\
\hline $\begin{array}{l}\text { Chicken } \\
\text { (cooked) }\end{array}$ & Listeria monocytogenes & $\begin{array}{l}1.4 \text { to } 4.7 \text { log reductions } \\
\text { after } 2 \text { minutes - } \\
\text { (dependent on gas } \\
\text { mixture) }\end{array}$ & $\begin{array}{l}\text { - } 2 \mathrm{kV}, 50 \mathrm{kHz} \\
\text { - Jet } \\
\text { - } \text { Direct } \\
\text { - } \mathrm{He}, \mathrm{O} 2, \mathrm{~N} 2\end{array}$ & 35 \\
\hline Eggs & Salmonella Enteritidis & $\begin{array}{l}2.2-2.5 \mathrm{log} \text { reductions } \\
\text { after } 90 \text { minutes at } 35 \% \\
\text { relative humidity }(\mathrm{RH}) . \\
\text { 3.8-4.5 log reductions } \\
\text { after } 90 \text { minutes at } 65 \% \\
\mathrm{RH} \text {. } \\
3.5 \mathrm{log} \text { reductions after } \\
90 \text { minutes at } 65 \% \mathrm{RH} \text {. }\end{array}$ & $\begin{array}{l}\text { - } 15 \mathrm{kV}, 12.7 \mathrm{kHz} \\
\text { - Volumetric DBD } \\
\text { - Indirect } \\
\text { - } \text { Air }\end{array}$ & 110 \\
\hline Ham & Listeria monocytogenes & $\begin{array}{l}1.9 \text { to } 6.5 \text { log reductions } \\
\text { after } 2 \text { minutes - } \\
\text { (dependent on gas } \\
\text { mixture). }\end{array}$ & $\begin{array}{l}\text { - } 2 \mathrm{kV}, 50 \mathrm{kHz} \\
\text { - Jet } \\
\text { - } \text { Direct } \\
\text { - } \mathrm{He}, \mathrm{O} 2, \mathrm{~N} 2\end{array}$ & 35 \\
\hline Ham & $\begin{array}{l}\text { Listeria monocytogenes } \\
\text { ( } 3 \text { strain cocktail) }\end{array}$ & $\begin{array}{l}0.25 \text { to } 1.73 \log \\
\text { reductions }\end{array}$ & $\begin{array}{l}\text { - } 75 \text { to } 125 \mathrm{~W} \text {, } \\
13.56 \mathrm{Mhz} \\
\text { - Volumetric DBD } \\
\text { - Direct } \\
\text { - He and } \mathrm{O}_{2}\end{array}$ & 108 \\
\hline Pork (raw) & E. coli & $\begin{array}{l}6 \text { log reductions after } 0.5 \\
\text { minutes }\end{array}$ & $\begin{array}{l}\text { - } 13.56 \mathrm{MHz}, 20 \text { to } \\
150 \mathrm{~W} \\
\text { - Volumetric DBD } \\
\text { - Direct } \\
\text { - Air }\end{array}$ & 111 \\
\hline
\end{tabular}




\section{FIGURES}

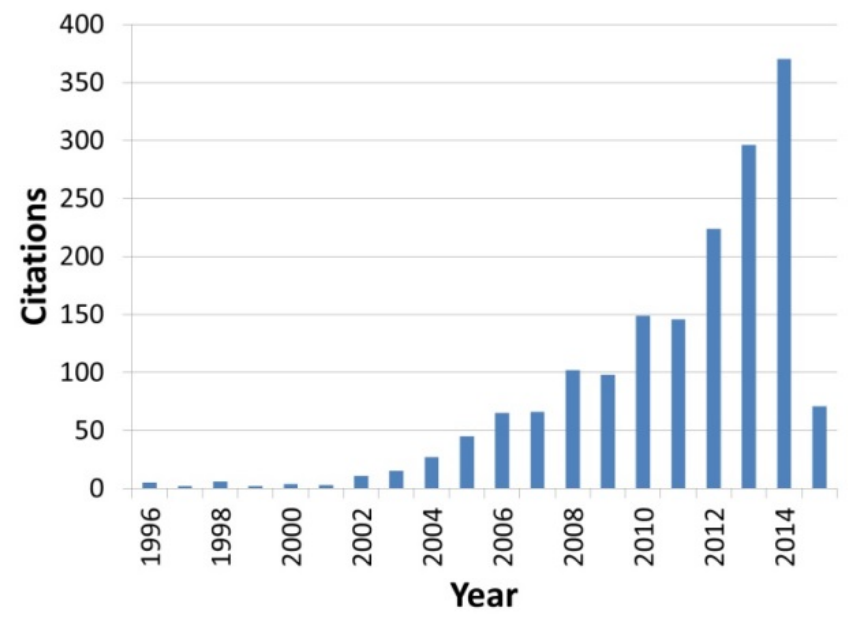

Figure 1. Citations per year of papers on plasma decontamination of food. (Source: Web of Science 2014) 
(a)

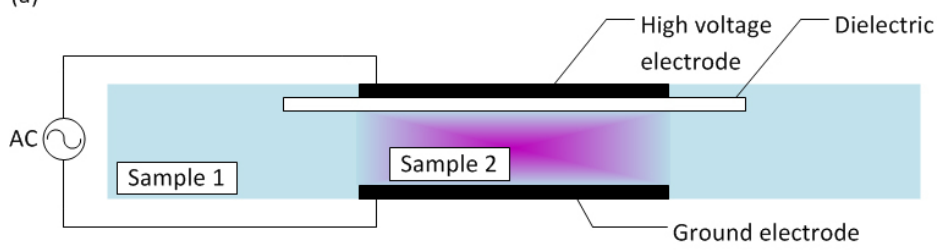

(b)

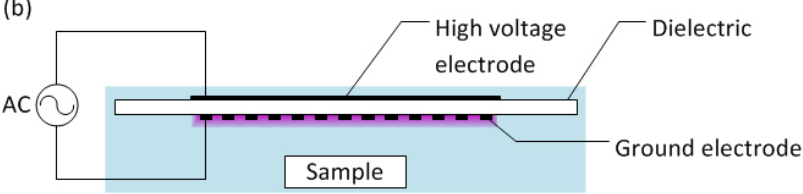

(c) Gas flow

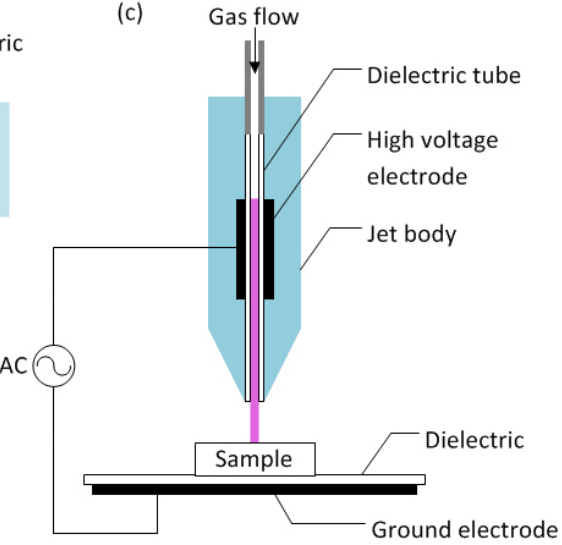

Figure 2. Three common configurations of DBD discharges that have been used for treating food. (a) volumetric DBD discharge (indirect (sample 1) and direct (sample 2) plasma treatment); (b) Surface DBD discharge (indirect plasma treatment); and (c) DBD plasma jet (localized direct plasma treatment). 

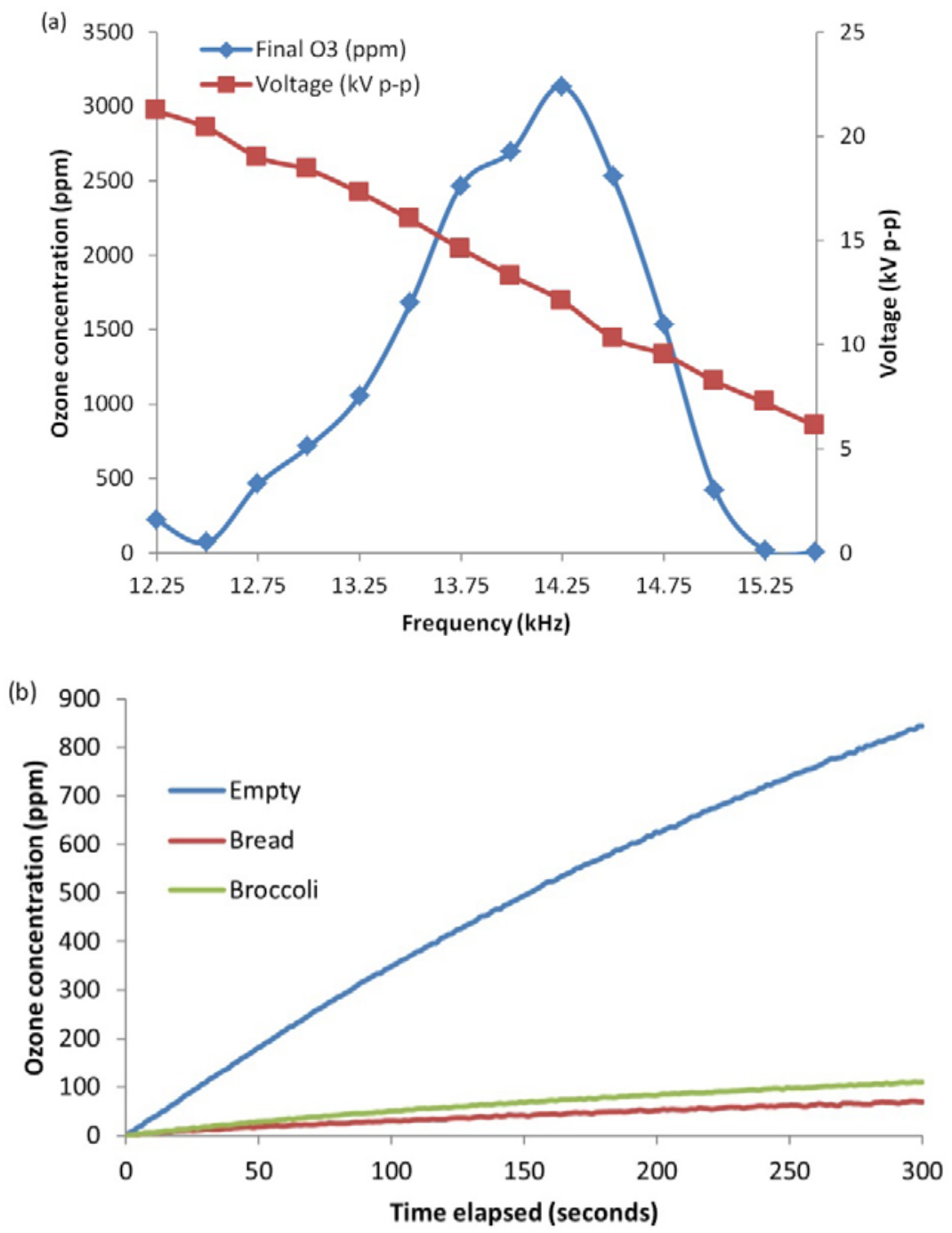

Figure 3. (a) Frequency dependence of peak to peak output voltage of a half-bridge resonant power supply (resonant frequency $12.25 \mathrm{kHz}$ ) used to ignite a surface DBD discharge in atmospheric air and the ozone concentration measured in a small enclosure $(\varnothing 7.5 \mathrm{~cm} \times 5 \mathrm{~cm})$ after 5 minutes of operation when the power supply is operated with a constant duty cycle of $20 \%$ (b) Food loading effect on the build-up of ozone concentration in a $30 \mathrm{~cm} \times 30 \mathrm{~cm} x 20 \mathrm{~cm}$ chamber by means of a surface DBD discharge operated in atmospheric air. The reduced ozone concentration due to the food loading effect will inevitably affect the bactericidal properties of the plasma. 


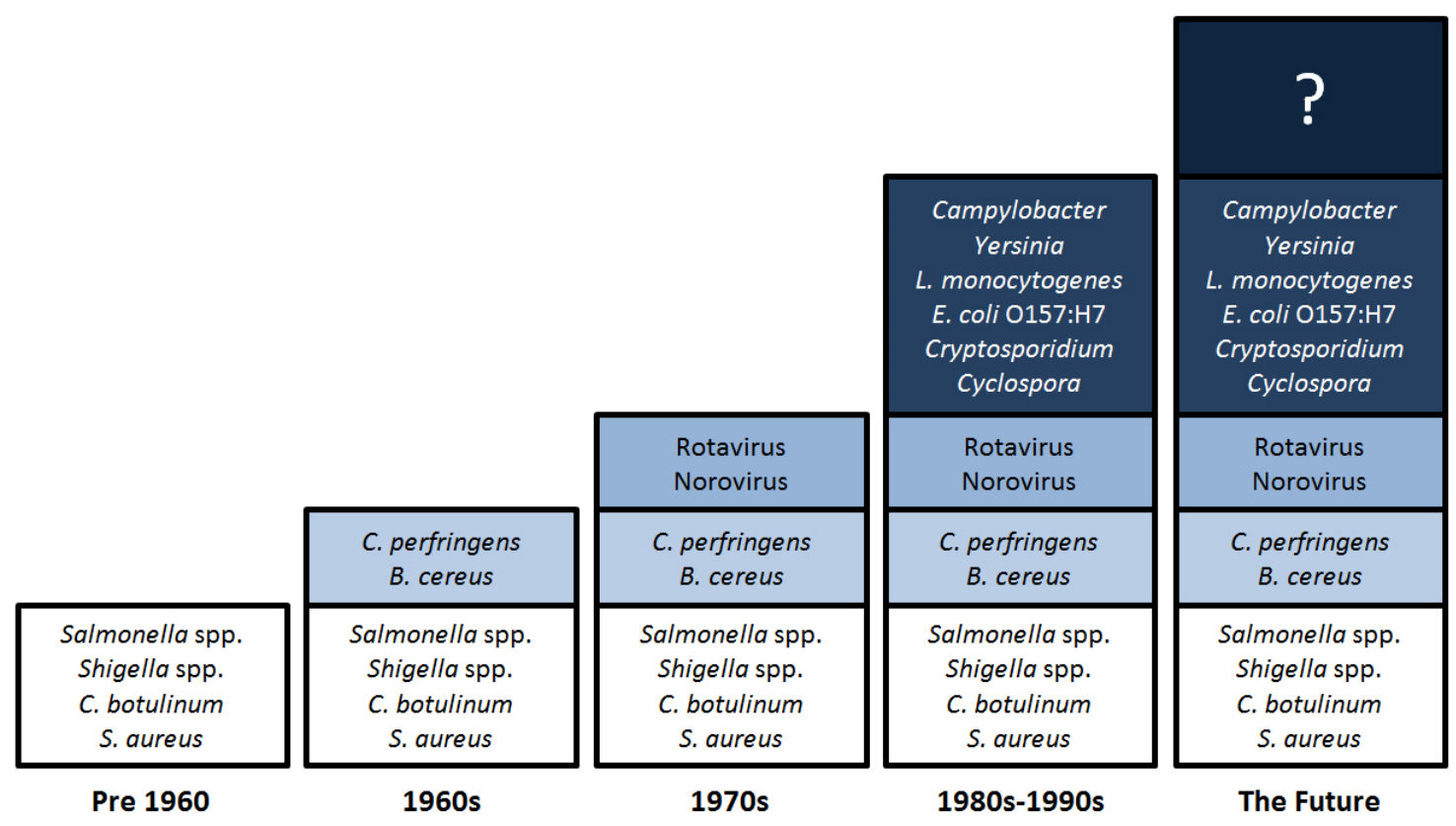

Figure 4. The increasing burden of foodborne disease - Drawn using information presented by Newell et al., (2010). ${ }^{101}$ 


\section{REFERENCES}

${ }^{1}$ S. Brodt, K.J. Kramer, A Kendall and G. Feenstra, Food Policy, 42, 106 (2013).

${ }^{2}$ D.A. Freedman and K.D. Bess, American Journal of Community Psychology 47, 397 (2011).

${ }^{3}$ L.M. Wein and Y. Liu, Proceedings of the National Academy of Sciences 102, 9984 (2005).

${ }^{4}$ C. Medus et al, Journal of the American Medical Association 301, 1119 (2009).

${ }^{5}$ L.H. Gould, K.A. Walsh, A.R. Vieira, K. Herman, I.T. Williams, A.J. Hall and D. Cole, Centers for Disease Control and Prevention MMWR 62, 2 (June 2013).

${ }^{6}$ J.E. Grass, H.L. Gould, B.E. Mahon, Foodborne Pathogens and Disease 10, 131 (2013).

${ }^{7}$ A.H. Havelaar, J.A. Haagsma, M.J. Mangen et al, International Journal of Food Microbiology 156, 231 (2012).

${ }^{8}$ H.-P. Su, S.-I. Chiu, J.-L. Tsai, C.-L. Lee, and T.-M. Pan, J. Infect. Chemother. 11, 146 (2005).

${ }^{9}$ C.R. Lane et al, Emerging Infectious Diseases 20, 1097 (2014).

${ }^{10}$ T.E. Quested, P.E. Cook, L.G.M. Morris and M.B. Cole, International Journal of Food Microbiology 139, S29 (2010).

${ }^{11}$ G.K. Adak, S.M. Meakins, H. Yip, B.A. Lopman and S.J. O’Brien, Emerging Infectious Diseases 11, 365 (2005).

${ }^{12}$ P.J. Taormina L.R. Beuchat and L. Slutsker, Emerging Infectious Diseases 5, 626 (1999).

${ }^{13}$ B.J. Silk et al, Morbidity and Mortality Weekly Report 62, 448 (2013).

${ }^{14}$ A.M. Dechet, K.M. Herman, C.C. Parker, P. Taormina, J. Johanson, R.V. Tauxe and B.E. Mahon, Foodborne Pathogens and Disease 11, 635 (2014).

15 “Outbreaks of E. coli O104:H4 infection: update 30”, World Health Organization (22 July 2011).

${ }^{16}$ R. Burger "EHEC O104:H4 in Germany 2011: Large Outbreak of Bloody Diarreha and Haemolytic Uraemic Syndrome by Shiga Toxin-producing E. coli via Contaminated Food” in Improving Food Safety Through a One Health Approach: Workshop Summary, National Academies Press, US (2012).

${ }^{17}$ M.A. Obande, G.A. Tucker and G. Shama, Postharvest Biology and Technology 62, 188 (2011).

18 “The Food Recovery Hierarchy”, United States Environmental Protection Agency (2014)

19 "New estimates for household food and drink water in the UK", The Waste and Resources Action Programme (2011).

${ }^{20}$ M.R. Corbo, A. Bevilacqua, D. Campaniello, D. D’Amato, B. Speranza, and M. Sinigaglia, International Journal of Food Science \& Technology 44, 223 (2009).

${ }^{21}$ P. Basaran, N. Basaran-Akgul and L. Oksuz, Food Microbiology 25, 626 (2008).

${ }^{22}$ C. Pignata et al, Journal of Applied Microbiology 116, 1137 (2014).

${ }^{23}$ J. Kim, D. Lee and S. Min, Food Microbiology 38, 128 (2014).

${ }^{24}$ B. Šerá, I. Gajdová, M. Šerý, and P. Špatenka, Plasma Sci. Technol. 15, 935 (2013).

${ }^{25}$ S. Perni, G. Shama and M.G. Kong, Journal of Food Protection 71, 1619 (2008).

${ }^{26}$ N. Misra et al, Food Bioprocess Technology 7, 3045 (2014).

${ }^{27}$ B. Kim, H. Yun, S. Jung, Y. Jung, H. Jung, W. Choe and C. Jo, Food Microbiology 28, 9 (2011).

${ }^{28}$ D. Bermidez-Aguirre, E. Wemlinger, P. Pedrow, G. Barbosa-Canovas and M. Garcia-Perez, Food Control 34, 149 (2013).

${ }^{29}$ B. Niemira, Journal of Food Science 77, M171 (2012).

${ }^{30}$ N. Ekem, T. Akan, Y. Akgun, A. Kiremitci, S. Pat, and G. Musa, Surface and Coatings Technology 201, 993 (2006).

${ }^{31}$ U. Schnabel, R. Niquet, U. Krohmann, J. Winter, O. Schlüter, K.-D. Weltmann, and J. Ehlbeck, Plasma Processes Polym. 9, 569 (2012).

${ }^{32}$ M. Selcuk, L. Oksuz, and P. Basaran, Bioresource Technology 99, 5104 (2008).

${ }^{33}$ S. Deng, R. Ruan, C. H. Mok, G Huang, X. Lin and P. Chen, Journal of Food Science 72, M62 (2007).

${ }^{34}$ A. Mitra, Y.-F. Li, T.G. Klämpfl, T. Shimizu, J. Jeon, G.E. Morfill, and J.L. Zimmermann, Food Bioprocess Technol 7, 645 (2014). 
${ }^{35}$ H. Lee, H. Jung, W. Choe, J. Ham, J. Lee and C. Jo, Food Microbiology 28, 1468 (2011).

${ }^{36}$ A. Mai-Prochnow, A. B. Murphy, K.M. McLean, M.G. Kong and K. Ostrikov, International Journal of Antimicrobial Agents, 43, 508 (2014).

${ }^{37}$ A. Sakudo, N. Shimizu, Y. Imanishi, and K. Ikuta, BioMed Research International 2013, 694269 (2013).

${ }^{38}$ B. J. Park, D. H. Lee, J. C. Park, I.S . Lee, K. Y. Lee, S.O. Hyun, M.S. Chun and K.H. Chung. Physics of Plasmas, 10, 4539, (2003)

${ }^{39}$ M. Vleugels, G. Shama, X.T. Deng, E. Greenacre, T. Brocklehurst and M.G. Kong, IEE Transactions on Plasma Science, 33, 824, (2005).

${ }^{40}$ J.L. Zimmermann, T. Shimizu, H.-U. Schmidt, Y.-F. Li, G.E. Morfill, and G. Isbary, New J. Phys. 14, 073037 (2012).

${ }^{41}$ U. Kogelschatz, Plasma Chem. Plasma Process. 23, 1 (2003).

${ }^{42}$ D.L. Bayliss, J.L. Walsh, F. Iza, G. Shama, J. Holah, and M.G. Kong, Plasma Processes and Polymers 9, 597 (2012)

${ }^{43}$ E. Doležalová E., A. Shaw, F. Iza, G. Shama, M. Šimek, Proceedings to the 14th International Symposium on High Pressure Low Temperature Plasma Chemistry (HAKONE XIV), Greifswald (2014)

${ }^{44}$ X. Deng, J. Shi, and M.G. Kong, IEEE Transactions on Plasma Science 34, 1310 (2006).

${ }^{45}$ A. von Keudell, P. Awakowicz, J. Benedikt, V. Raballand, A. Yanguas-Gil, J. Opretzka, C. Flötgen, R. Reuter, L. Byelykh, H. Halfmann, K. Stapelmann, B. Denis, J. Wunderlich, P. Muranyi, F. Rossi, O. Kylián, N. Hasiwa, A. Ruiz, H. Rauscher, L. Sirghi, E. Comoy, C. Dehen, L. Challier, and J.P. Deslys, Plasma Processes Polym. 7, 327 (2010).

${ }^{46}$ M.K. Boudam and M. Moisan, J. Phys. D: Appl. Phys. 43, 295202 (2010).

${ }^{47}$ A. Mahfoudh, M. Moisan, J. Séguin, J. Barbeau, Y. Kabouzi, and D. Kéroack, Ozone: Science \& Engineering 32, 180 (2010).

${ }^{48}$ M. Heise, W. Neff, O. Franken, P. Muranyi and J. Wunderlich, Plasmas and Polymers 9, 23 (2004).

${ }^{49}$ H. Yun, B. Kim, S. Jung, Z.A. Kruk, D.B. Kim, W. Choe and C. Jo, Food Control 21, 1182 (2010).

${ }^{50}$ M. Deilmann, H. Halfmann, N. Bibinov, J. Winderlich and P. Awakowicz, Journal of Food Protection 71, 2119 (2008).

${ }^{51}$ A.A. Kader, D. Zagory, E.L. Kerbel, and C.Y. Wang, Critical Reviews in Food Science and Nutrition 28, 1 (1989).

52 J. Farber, J. Food Prot. 54, 58 (1991).

${ }^{53}$ D. Ziuzina, S. Patil, P.J. Cullen, K.M. Keener and P. Bourke, Food Microbiology 42, 109 (2014).

${ }^{54}$ H.E. Potts, D.A. Diver, P.C. Everest, and R.D. O’Connor, in Proceedings of The 30th International Conference on Phenomena in Ionized Gases (Belfast, 2011), p. 296.

55 J.L. Walsh, F. Iza, N.B. Janson, V.J. Law, and M.G. Kong, Journal of Physics D: Applied Physics 43, 075201 (2010).

${ }^{56}$ H. Huang, TI Literature Number SLUP263, Texas Instruments Power Supply Design Seminar (2010)

${ }^{57}$ Plasma Medicine: Applications of Low-Temperature Gas Plasmas in Medicine and Biology, Ed. M. Laroussi, M. G. Kong, G. Morfill and W. Stolz, Cambridge University Press (2012)

${ }^{58}$ A. Friedman and Gary Friedman, Plasma Medicine, John Wiley \& Sons, Ltd (2013)

${ }^{59}$ T. von Woedtke, S. Reuter, K. Masur, and K.-D. Weltmann, Physics Reports 530, 291 (2013).

${ }^{60}$ J.W. Coburn and H.F. Winters, Journal of Vacuum Science and Technology 16, 391 (1979).

${ }^{61}$ M. Moisan, J, Barbeau, S. Moreau, J. Pelletier, M. Tabrizian and L.H. Yahia, International Journal of Pharmaceutics, 226, 1, (2001).

${ }^{62}$ J. Opretzka, J. Benedikt, P. Awakowicz, J. Wunderlich and A. von Keudell, Journal of Physics D Applied Physics, 40, 2826, (2007).

${ }^{63}$ M. Moisan, J. Barbeau, M.-C. Crevier, J. Pelletier, N. Philip, and B. Saoudi, Pure Appl. Chem. 74, 349 (2002).

${ }^{64}$ S. Perni S, G. Shama J. L. Hobman, P. A. Lund, C. J. Kershaw, G. A. Hidalgo-Arroyo, C. W. Penn, X. T. Deng, J. L. Walsh and M. G. Kong, Applied Physics Letters 90, 073902, (2007).

${ }^{65}$ F. Judee, G. Wattieaux, N. Merbahi, M. Mansour and M. P. Castanie-Cornet, Journal of Physics D: Applied Physics, 47, 405201, (2014).

${ }^{66}$ D.B. Graves, J. Phys. D: Appl. Phys. 45, 263001 (2012). 
${ }^{67}$ Y. Sakiyama, D.B. Graves, H.-W. Chang, T. Shimizu, and G.E. Morfill, Journal of Physics D: Applied Physics 45, 425201 (2012).

${ }^{68}$ K. McKay, D.X. Liu, M.Z. Rong, F. Iza, and M.G. Kong, Journal of Physics D: Applied Physics 45, 172001 (2012).

${ }^{69}$ Z. Machala, B. Tarabova, K. Hensel, E. Spetlikova, L. Sikurova, and P. Lukes, Plasma Processes and Polymers, 10, 649, (2013).

${ }^{70}$ B. Halliwell and J.M.C. Gutteridge, Free Radicals in Biology and Medicine, 4th ed. (Clarendon Press, Oxford, 2007).

${ }^{71}$ A. Sharma, G. Collins and A. Pruden, Journal of Applied Microbiology, 107, 1440, (2009).

72 J-W. Lackmann and J.E. Bandow, Applied Microbiology and Biotechnology, 98, 6205, (2014).

${ }^{73}$ M. Hoentsch, R. Bussiahn, H. Rebl, C. Bergemann, M. Eggert, M. Frank, T. von Woedtke, and B. Nebe, PLoS ONE 9, e104559 (2014).

${ }^{74}$ M.J. Traylor, M.J. Pavlovich, S. Karim, P. Hait, Y. Sakiyama, D.S. Clark, and D.B. Graves, J. Phys. D: Appl. Phys. 44, 472001 (2011).

${ }^{75}$ P. Lukes, E. Dolezalova, I. Sisrova, and M. Clupek, Plasma Sources Sci. Technol. 23, 015019 (2014).

${ }^{76}$ S. Hamaguchi, in AIP Conference Proceedings 1545, 214 (2013)

${ }^{77}$ C. Chen, D. X. Liu, Z. C. Liu, A. J. Yang, H. L. Chen, G. Shama, and M. G. Kong, Plasma Chem Plasma Process. 34, 403 (2014).

${ }^{78}$ S. Tappi, A. Berardinelli, L. Ragni, M. Rosa, A. Guarnieri and P. Rocculi, Innovative Food Science and Emerging Technologies 21, 114 (2014).

${ }^{79}$ A. Frohling, J. Durek, U. Schnabel, J. Ehlbeck, J. Bolling and O. Schluter, Innovative Food Science and Emerging Technologies 16, 381 (2012).

${ }^{80}$ N.N. Misra, S. Patil, T. Moiseev, P. Bourke, J.P. Mosnier, K.M. Keener and P.J. Cullen, Journal of Food Engineering 125, 131 (2014).

${ }^{81}$ N.N. Misra, K.M. Keener, P. Bourke, J. Mosnier and P.J. Cullen, Journal of Bioscience and Bioengineering 118, 177 (2014).

${ }^{82}$ A. Doubla, L. Bouba Bello, M. Fotso, and J.-L. Brisset, Dyes and Pigments 77, 118 (2008).

${ }^{83}$ K. Oehmigen, M. Hähnel, R. Brandenburg, C. Wilke, K.-D. Weltmann, and T. von Woedtke, Plasma Processes Polym. 7, 250 (2010).

${ }^{84}$ V. Rodov, S. Benyehoshua, R. Albagli and D.Q. Fang, Postharvest Biology and Technology, 5, 119, (1995).

${ }^{85}$ G. Shama and P. Alderson, Trends in Food Science and Technology, 16, 128, (2005).

${ }^{86}$ G. Shama, Postharvest Biology and Technology, 44, 1, (2007).

${ }^{87}$ B.I. Nwaru et al, European Journal of Annergy and Clinical Immunology 69, 62 (2013).

${ }^{88}$ X. Wang, O.A. Young and D.P. Karl, Journal of Food Science 75, T149 (2010).

${ }^{89}$ D.L. Bayliss, J.L. Walsh, G. Shama, F. Iza, and M.G. Kong, New J. Phys. 11, 115024 (16pp) (2009).

${ }^{90}$ H. Shintani, N. Shimizu, Y. Imanishi, T. Sekiya, K. Tamazawa, A. Taniguchi, and N. Kido, Biocontrol Sci 12, 131 (2007).

${ }^{91}$ A.M Cheraghali and H. Yazdanpanah, Journal of Food Safety, 30, 382, (2010).

${ }^{92}$ A. Rajkovic, Trends in Food Science and Technology, 38, 149, (2014).

${ }^{93}$ B.M. Kaikotlhaile, P. Spanoghe and W. Steurbaut, Food Chemical and Toxicology 48, 1 (2010).

${ }^{94}$ S.H. Kim, J.H. Kim, and B.-K. Kang, Langmuir 23, 8074 (2007).

${ }^{95}$ Y. Bai, J. Chen, H. Mu, C. Zhang and B. Li, Journal of Agriculture and Food Chemistry 57, 6238 (2009).

${ }^{96}$ Y. Bai, J. Chen, Y. Yang, L. Guo and C. Zhang, Chemosphere 81, 408 (2010).

${ }^{97}$ Z. Shareefdeen, B. Herner, D. Webb and S. Wilson, Environmental Progress 22, 207 (2003).

${ }^{98}$ R.H. Zhang, Y. Yin, T. Yamamoto and D.S. Bundy, IEEE Industry Applications Society Annual Meeting 1-3, 1545 (1994).

${ }^{99}$ K.B. Andersen, J.A. Beukes and L. Feilberg, Chemical Engineering Journal 223, 638 (2013).

${ }^{100}$ K.B. Andersen, A. Feilberg and J.A. Beukes, International Conference on Environmental Odour Monitoring and Control 23, 351 (2010).

${ }^{101}$ D.G. Newell, M. Koopmans, L. Verhoef, E. Duizer, A. Aidara-Kane, H. Sprong, M. Opsteegh, M. Langelaar, J. Threfall, F. Scheutz, J. van der Giessen, and H. Kruse, International Journal of Food Microbiology 139, S3 (2010).

102 P.J. Taormina, Crit Rev Food Sci Nutr 50, 209 (2010). 
${ }^{103}$ A.H. Havelaar, S. Brul, A. de Jong, R. de Jonge, M.H. Zwietering, and B.H. ter Kuile, International Journal of Food Microbiology 139, S79 (2010).

104 B. Niemira and J Sites, Journal of Food Protection 71, 1357 (2008).

${ }^{105}$ F. Critzer, K. Kelly-Wintenberg, S. South and D. Golden, Journal of Food Protection 70, 2290 (2007).

${ }^{106}$ A. Fernandez, E. Noriega and A. Thompson, Food Microbiology 33, 24 (2013).

${ }^{107}$ M. Baier, J. Foerster, U. Schnabel, D. Knorr, J. Ehlbeck, W.B. Herppich and O. Schlüter, Postharvest Biology and Technology 84, 81 (2013).

${ }^{108}$ H. Song, B. Kim, J. Choe, S. Jung, S. Moon, W. Choe and C. Jo, Food Microbiology 26, 432 (2009).

${ }^{109}$ E. Noriega, G. Shama, A. Laca, M. Diaz and M.G. Kong, Food Microbiology 28, 1293 (2011).

${ }^{110}$ L. Ragni, A. Berardinelli, L. Vannini, C. Montanari, F. Sirri, M. Guerzoni and A. Guarnieri, Journal of Food Engineering 100, 125 (2010).

${ }^{111}$ S. Moon, D.B. Kim, B. Gweon, W. Choe, H.P. Song and C. Jo, Thin Solid Films 517, 4272 (2009). 